$1^{\text {st }}$ International Multidisciplinary Conference on Nutraceuticals and Functional Foods

Current Research in Nutrition and Food Science

Vol. 4(SI. 2), 105-113 (2016)

\title{
Effect of Enrichment of Bovine Milk with Whey Proteins on Biofunctional and Rheological Properties of Low Fat Yoghurt- type Products
}

\author{
DIMITRIS ROUMANAS, GOLFO MOATSOU, EVANGELIA ZOIDOU, \\ LAMBROS SAKKAS and EKATERINI MOSCHOPOULOU*
}

\author{
Laboratory of Dairy Research, Dept. of Food Science and Human Nutrition Agricultural \\ University of Athens, lera Odos 75, 11855, Athens, Greece.
}

http://dx.doi.org/10.12944/CRNFSJ.4.Special-Issue-October.14

(Received: August, 2016; Accepted: September 17, 2016)

\begin{abstract}
In this study, the effect of supplementation of low fat bovine milk with whey protein concentrates (WPC) or whey protein hydrolysates (WPH) on the biofunctional and rheological properties of the produced yoghurt was assessed. Six different set type yoghurt products containing $1.6 \%$ fat were manufactured and enriched with: a) $1.5 \%$ bovine WPC (80\% protein), marked as WPC_A yoghurt, b) $1 \%$ WPC ( $80 \%$ protein) of ovine/caprine origin, marked as WPC_B yoghurt, c) $2 \%$ commercial mixture of milk proteins, i.e. milk protein concentrate/ caseinates /WPC (82\% total protein content), marked as MPM yoghurt, d) $0.25 \%$ WPC_B hydrolysed with trypsin, marked as WPH_A yoghurt, e) $0.5 \%$ commercial WPH, marked as WPH_B1yoghurt, f) $0.25 \%$ commercial WPH, marked as WPH_B2 yoghurt. Control yoghurt was manufactured without addition of protein. Results showed that the protein fortification level affected positively the protein, total solids as well as calcium and phosphorous contents of all yoghurt types. The lowest $\mathrm{pH}$ values were observed in the case of WPH_B2 yoghurt, while the highest in the case of MPM yoghurt throughout the storage i.e. 21 days. The characteristic microorganisms were in total more than $10^{8} \mathrm{cfu} / \mathrm{g}$. Yoghurts fortified with WPH showed higher ACE-inhibitory activity (determined by the HPLC method) than those enriched with WPC. Also, it is noteworthy that WPH_A yoghurt showed significantly $(P<0.05)$ higher ACE-inhibitory activity $(72 \%)$ than control yoghurt or yoghurts made with the other WPH. On the other hand, WPH_A yoghurt showed the lowest hardness and adhesiveness, whereas MPM yoghurt showed the highest. The type of added whey protein did not affect cohesiveness. Water holding capacity was higher in yoghurts enriched with WPC and MPM than in the yoghurts enriched with WPH. All yoghurts presented antioxidant activity such as $\mathrm{DPPH}^{\circ}$ radical scavenging activity (45-58\%). The WPC_A yoghurt, MPM yoghurt, WPH_A yoghurt and control yoghurt presented high $\mathrm{Fe}^{2+}$ chelating activity (>70\%), but WPH_A yoghurt presented the highest $\mathrm{Fe}^{2+}$ chelating activity (>95\%) throughout storage. In conclusion, fortification of yoghurt milk with WPH increased the biofunctionality of the product, but the use of WPH of ovine/caprine origin increased it significantly.
\end{abstract}

Keywords: Yoghurt, Whey Protein Concentrate, Whey Protein Hydrolysate, Textural properties, ACE-I inhibitory activity, Antioxidant Properties.

\section{INTRODUCTION}

Fermented milk products are value added food products in terms of nutritional and biofunctional properties. Their nutrition function concerns improvement of protein digestibility, alleviation of lactose intolerance and enhancement of mineral absorption. The biofunctional effects include control of intestinal health, lowering serum cholesterol, antihypertensive effects, anticancer effects and effect on immunological function ${ }^{1,2}$. 
In yoghurt production it is a common practice to fortify the milk with extra milk proteins for improving the textural properties particularly in the case of set type and low fat products. The added milk proteins are usually in the form of skimmed milk powder (SMP), whey protein concentrates (WPC), whey protein hydrolysates (WPH), whey protein isolates (WPI) or sodium-calcium caseinates (SCC $)^{3,4,5}$. Moreover, it has been showed that except texture improvement, addition of SCC, WPC or SMP at specific ratios may increase the nutritional value of this product ${ }^{6,7}$. Generally, the most commonly used milk proteins powders are of bovine origin. To our knowledge, WPH of ovine or/and caprine origin are not available in the market and may have not been used in yoghurt production. The objective of this study was to evaluate the textural and some biofunctional properties of set type yoghurt made from low fat bovine milk supplemented with different products of whey proteins powders including WPC and WPH of ovine/caprine origin.

\section{MATERIALS AND METHODS}

Pasteurized and homogenized bovine milk (1.5\% fat, $3.3 \%$ protein) was used and 6 set type yoghurt products were manufactured using different whey protein powders at various ratios as showed in Table 1. The control yoghurt was not fortified. Protein content of the whey powders ranged from 80 to $86 \%$. WPC WHEY PRO 80 was provided by Hellenic Protein S.A. The commercial blend of MPC/ CN/WPC as well as the hydrolyzed WPI (OPTIPEP 90 SN) was provided by Alinda S.A. The Hydrolyzed WHEY PRO 80 with trypsin was an experimental preparation $^{8}$. Milk formulations were homogenized with the aid of Ultra Turrax ${ }^{\circledR}$ and then they remained at $4^{\circ} \mathrm{C}$ for $24 \mathrm{~h}$. Next day, they were heated at $95^{\circ} \mathrm{C}$ for $2 \mathrm{~min}$, cooled at $42^{\circ} \mathrm{C}$ and inoculated with Greek traditional yoghurt at a ratio $1.5 \%$. The inoculated milks were then poured into $100 \mathrm{~g}$ sterilized plastic containers and incubated at $42^{\circ} \mathrm{C}$ until a $\mathrm{pH} 4.7$ was reached. After fermentation, all yoghurts were stored at $4^{\circ} \mathrm{C}$ for 21 days and were analyzed for their physicochemical, textural and biofunctional properties. Three replicated experimental trials were carried out. Unless otherwise stated, all analyses were performed in duplicate.

\section{Compositional analyses}

Yoghurt protein content, fat content and total solids were determined on Foodscan (Foss Electric, Denmark) instrument. For ash content determination, $10 \mathrm{~g}$ of yoghurt sample were placed in a silica crucible, heated in an oven by increasing the temperature by $50^{\circ} \mathrm{C} / \mathrm{h}$ up to $550^{\circ} \mathrm{C}$ and maintained at $550^{\circ} \mathrm{C}$ for $6 \mathrm{~h}^{9}$. Lactose content was estimated using the equation: \%Total solids= \%Protein content $+\%$ Fat content $+\%$ Ash content $+\%$ Lactose content. $\mathrm{pH}$ was determined using a $\mathrm{pH}$ meter (Orion Star 3) and the titratable acidity, expressed as Dornic degrees $\left({ }^{\circ} \mathrm{D}\right)$, was determined by titration of $10 \mathrm{~g}$ yoghurt sample with $\mathrm{N} / 9 \mathrm{NaOH}$ using a $1 \%$ phenolphthalein solution as indicator.

Determination of the inorganic fraction Calcium, Magnesium, Sodium and Potassium in the ash fraction was carried out by means of the atomic absorption spectrometric (AAS) method $^{9}$ using a Shimadzu AA-6800 Atomic Absorption Spectrophotometer equipped with the autosampler Shimadzu ASC-6100 and the software WizAArd v.

Table 1: Whey powder products used in the produced yoghurts

\begin{tabular}{lccc}
\hline Yoghurt & Type of added whey protein & $\begin{array}{c}\text { Protein content } \\
\text { (g/100 g powder) }\end{array}$ & $\begin{array}{c}\text { Ratio of addition } \\
(\% \mathbf{w} / \mathbf{w})\end{array}$ \\
\hline WPC_A & Bovine WPC 80 standard & 80 & 1.5 \\
WPC_B & ovine/caprine WHEY PRO 80 & 80 & 1 \\
MPM & Bovine commercial blend (MPC/CN/WPC) & 82 & 2 \\
WPH_A & Hydrolyzed WHEY PRO 80 with trypsin & 80 & 0.25 \\
WPH_B1 & Hydrolyzed WPI & 86 & 0.5 \\
WPH_B2 & Hydrolyzed WPI & 86 & 0.25 \\
CONTROL & - & - & - \\
\hline
\end{tabular}


2.30. Phosphorous content was also determined in the ash fraction of yoghurts using molecular absorption spectrometry ${ }^{10}$.

The characteristic microorganisms of yoghurt as well as yeasts and moulds were enumerated using the colony count technique and specific growth conditions ${ }^{11,12}$.

\section{Textural properties}

Hardness, adhesiveness and cohesiveness were measured on a Shimadzu Testing Instrument, model AGS-500 NG (Shimadzu Corporation, Kyoto, Japan) equipped with a $5 \mathrm{~kg}$ load cell and a plunger with a diameter of $25 \mathrm{~mm}$. The speed of the plunger was $120 \mathrm{~mm} \cdot \mathrm{min}^{-1}$, in a downward direction, and yoghurt sample temperature was $10^{\circ} \mathrm{C}^{13}$.

The water holding capacity (WHC) was measured by a centrifugal method as follows: A sample of $20 \mathrm{~g}$ of yoghurt was centrifuged at $5000 \mathrm{~g}$ for $10 \mathrm{~min}$ at $20^{\circ} \mathrm{C}$ and then the whey expelled (w) was removed and weighed. The WHC $(\mathrm{g} / 100 \mathrm{~g})$ was calculated as: WHC (\%) $=100(20-w) / 20$.

\section{Antioxidant properties}

The $\mathrm{DPPH}^{\bullet}$ radical scavenging activity of yoghurt samples was determined using the spectrophotometric method ${ }^{6}$ with some modifications. One hundred $\mu \mathrm{l}$ of yoghurt sample or methanol (as control) or Trolox solution $0.25 \mathrm{mg} / \mathrm{ml}$ of a $4: 1$ methanol-water mixture (as a reference antioxidant) were mixed with $720 \mu \mathrm{l}$ of methanol and $80 \mu \mathrm{l}$ of 1 $\mathrm{mM}$ DPPH' solution in methanol. Blank tests for all samples, control and Trolox took place at the same time by replacing DPPH`solution with pure methanol. All mixtures were stirred thoroughly, incubated in dark and at room temperature for $30 \mathrm{~min}$, centrifuged at $10000 \mathrm{rpm}$ for $5 \mathrm{~min}$ and the supernatant was filtered with $0.45 \mu \mathrm{m}$ syringe filter (PVDF, Whatman). Two hundreds and fifty $\mu$ of filtered extracts were pipetted at 96-well microplates and after $10 \mathrm{~min}$ absorbance was measured at $517 \mu \mathrm{m}$ using a spectrometer ELISA (TECAN Sunrise). Scavenging activity was estimated using the equation: SCA\% $=100^{*}\left[\left({\text { A } 517_{\text {CONTROL }}}-\mathrm{A} 517_{\text {SAMPLE }}\right) /\right.$ A $\left.17_{\text {CONTROL }}\right]$. All determinations were carried out in triplicate.

The $\mathrm{Fe}^{2+}$ chelating activity of yoghurts was also determined by the spectrophotometric method 6 with some modifications. Two $\mathrm{ml}$ of yoghurt sample solution $(1 \mathrm{~g} / \mathrm{ml}$ in ultra-pure water) was diluted with $5.6 \mathrm{ml}$ of ultra-pure water and centrifuged (9500 rpm x 10min) and the supernatant was filtered with Whatman No 1. After, $190 \mu$ of the filtrate or ultrapure water (as control) or EDTA solution of $0.1 \mathrm{mg} /$ $\mathrm{ml}$ (as a reference antioxidant) were mixed with $20 \mu \mathrm{l}$ of $0.5 \mathrm{mM} \mathrm{FeSO}_{4}$ solution at 96-well microplates, stirred thoroughly and incubated in the dark and at room temperature for 30 and $60 \mathrm{~min}$. Then, $40 \mu \mathrm{l}$ of Ferrozine $1.25 \mathrm{mM}$ solution were added, the microplates were stirred thoroughly and after 10 min absorbance was measured at $562 \mathrm{~nm}$ using a spectrometer ELISA (TECAN Sunrise). Blank tests for all samples, control and EDTA took place at the same time by replacing Ferrozine solution with filtered ultra-pure water. Chelating activity was estimated using the equation:

$$
\begin{gathered}
\mathrm{SCA} \%=100 *\left[\left(\mathrm{~A}^{2} 62_{\mathrm{CONTROL}}-\mathrm{A} 562_{\text {SAMPLE }}\right) /\right. \\
\text { A562 } \left.{ }_{\text {CONTROL }}\right] .
\end{gathered}
$$

Table 2: Chemical composition $(\mathrm{g} / 100 \mathrm{~g})$ of low-fat bovine set-type yoghurts made with milk enriched with different whey protein powders (mean \pm std)

\begin{tabular}{lccccc}
\hline Yoghurt & Fat & Protein & Lactose & Ash & Total Solids \\
\hline WPC_A & $1.62 \pm 0.06^{\mathrm{a}, \mathrm{b}}$ & $4.46 \pm 0.15^{\mathrm{d}^{\star}}$ & $4.55 \pm 0.38$ & $0.82 \pm 0.02^{\mathrm{b}}$ & $11.45 \pm 0.16^{\mathrm{c}}$ \\
WPC_B & $1.62 \pm 0.05^{\mathrm{a}, \mathrm{b}}$ & $4.06 \pm 0.20^{\mathrm{c}}$ & $4.52 \pm 0.45$ & $0.81 \pm 0.02^{\mathrm{b}}$ & $11.02 \pm 0.20^{\mathrm{b}}$ \\
MPM & $1.60 \pm 0.06^{\mathrm{a}}$ & $4.87 \pm 0.11^{\mathrm{e}}$ & $4.71 \pm 0.41$ & $0.87 \pm 0.02^{\mathrm{c}}$ & $12.05 \pm 0.34^{\mathrm{d}}$ \\
WPH_A & $1.58 \pm 0.02^{\mathrm{a}}$ & $3.58 \pm 0.09^{\mathrm{a}, \mathrm{b}}$ & $4.86 \pm 0.14$ & $0.78 \pm 0.02^{\mathrm{a}}$ & $10.80 \pm 0.19^{\mathrm{a}, \mathrm{b}}$ \\
WPH_B1 & $1.61 \pm 0.03^{\mathrm{a}, \mathrm{b}}$ & $3.71 \pm 0.10^{\mathrm{b}}$ & $4.59 \pm 0.09$ & $0.79 \pm 0.02^{\mathrm{a}, \mathrm{b}}$ & $10.70 \pm 0.11^{\mathrm{a}, \mathrm{b}}$ \\
WPH_B2 & $1.64 \pm 0.04^{\mathrm{a}, \mathrm{b}}$ & $3.61 \pm 0.12^{\mathrm{a}, \mathrm{b}}$ & $4.71 \pm 0.14$ & $0.79 \pm 0.03^{\mathrm{a}, \mathrm{b}}$ & $10.74 \pm 0.29^{\mathrm{a}, \mathrm{b}}$ \\
CONTROL & $1.69 \pm 0.06^{\mathrm{b}}$ & $3.43 \pm 0.08^{\mathrm{a}}$ & $4.68 \pm 0.14$ & $0.78 \pm 0.01^{\mathrm{a}}$ & $10.58 \pm 0.28^{\mathrm{a}}$ \\
\hline
\end{tabular}

\footnotetext{
${ }^{*}$ Means in the same column differ each other significantly $(P<0.05)$
} 


\section{Anti-hypertensive properties}

The angiotensin converting enzyme (ACE-I) inhibitory activity of the yoghurt samples was determined by the RH-HPLC method ${ }^{14}$ with some modifications. In $200 \mathrm{ml}$ of yoghurt water soluble nitrogen fraction (diluted with ultra pure water at a ratio 1:2) or in 200 of ultra pure water (for control) $300 \mu \mathrm{l}$ of Hippuryl-L-histidyl-L-leucine (HHL) $5 \mathrm{mM}$ in borate buffer 8.3 was added and remained at $37^{\circ} \mathrm{C}$ for $5 \mathrm{~min}$. Then, $25 \mu \mathrm{l}$ of ACE $0.1 \mathrm{U} / \mathrm{ml}$ was added and left at $37^{\circ} \mathrm{C}$ for $60 \mathrm{~min}$. After, $225 \mu \mathrm{l} \mathrm{HCl} 1 \mathrm{~N}$ was added and filtered through syringe filter $0.45 \mu \mathrm{m}$. $\mathrm{RH}-\mathrm{HPLC}$ analysis was performed onto a column Nucleosil 300 C18 $4.6 \mathrm{~mm}$ using the solvents $0.1 \%$ triphthoro acetic acid (TFA) in ultra pure water and $0.1 \%$ TFA in $80 \%$ acetonitrile. Sample injection volume was $100 \mu \mathrm{l}$ and a gradient elution was applied at a flow rate $0.8 \mathrm{ml} / \mathrm{min}$.

\section{Statistical analysis}

The software Statgraphics Centurion XVI (Manugistics, Inc., Rockville, MA 20852, USA) was used for the assessment of the results. Oneway analysis of variance (ANOVA) was applied to data and the differences between averages were assessed with the LSD method at a level of significance $95 \%$.

\section{RESULTS AND DISCUSSION}

\section{Physicochemical and microbial composition}

Fortification of yoghurt milk with exogenous protein increases the protein content of the produced yoghurt ${ }^{3,4,5}$. Consequently, MPM yoghurt had significantly $(P<0.05)$ the highest protein and total solids contents due to the highest ratio of addition, whereas control yoghurt had the lowest
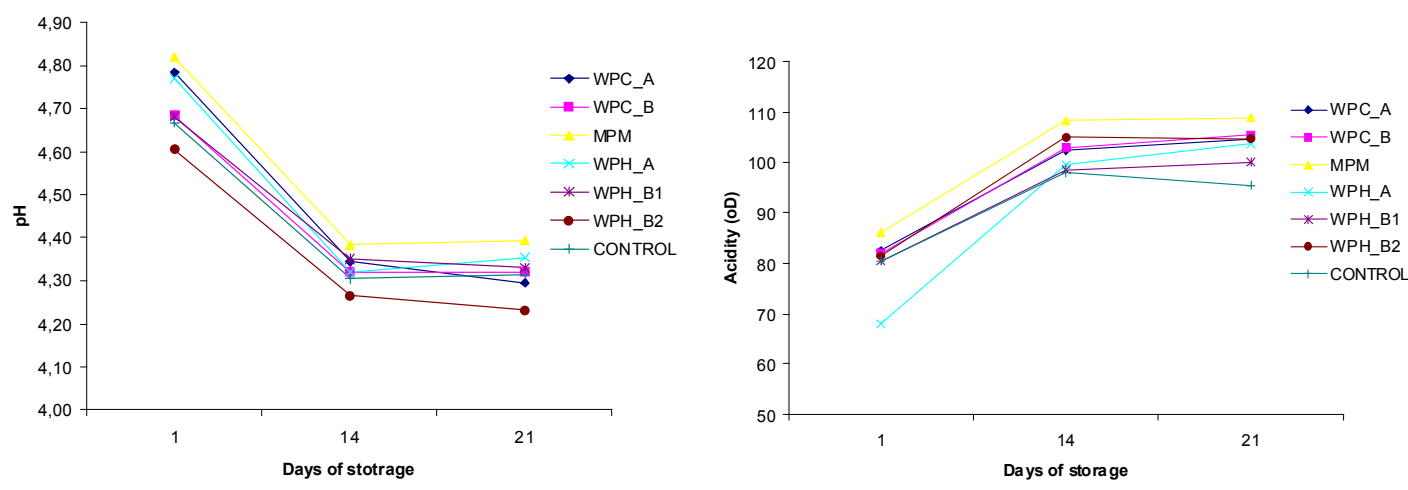

Fig.1: pH and acidity of low-fat bovine set-type yoghurts made with milk enriched with different whey protein powders

Table 3: Mineral content ( $\mathrm{mg} / \mathbf{1 0 0 \mathrm { g }}$ ) of low-fat bovine set-type yoghurts made with milk enriched with different whey protein powders (mean $\pm \mathrm{std}$ )

\begin{tabular}{lccccc}
\hline Yoghurt & Calcium & Magnesium & Potassium & Sodium & Phosphorus \\
\hline WPC_A & $105.09 \pm 2.74$ & $11.01 \pm 0.26^{\mathrm{a}^{\mathrm{a}}}$ & $138.44 \pm 7.52^{\mathrm{a}, \mathrm{b}}$ & $47.64 \pm 2.54^{\mathrm{a}}$ & $96.04 \pm 1.92^{\mathrm{a}, \mathrm{b}}$ \\
WPC_B & $99.36 \pm 7.98$ & $10.72 \pm 0.44^{\mathrm{a}, \mathrm{b}}$ & $133.93 \pm 4.05^{\mathrm{a}}$ & $45.65 \pm 2.86^{\mathrm{a}}$ & $94.23 \pm 2.48^{\mathrm{b}, \mathrm{c}}$ \\
MPM & $102.04 \pm 6.83$ & $9.98 \pm 0.20^{\mathrm{c}}$ & $138.22 \pm 9.96^{\mathrm{a}, \mathrm{b}}$ & $63.17 \pm 5.43^{\mathrm{b}}$ & $98.85 \pm 0.90^{\mathrm{a}}$ \\
WPH_A & $98.89 \pm 3.28$ & $11.07 \pm 0.63^{\mathrm{a}}$ & $142.89 \pm 2.64^{\mathrm{b}}$ & $48.44 \pm 3.27^{\mathrm{a}}$ & $94.75 \pm 2.07^{\mathrm{b}, \mathrm{c}}$ \\
WPH_B1 & $96.87 \pm 6.79$ & $11.02 \pm 0.33^{\mathrm{a}}$ & $132.21 \pm 8.56^{\mathrm{a}}$ & $47.62 \pm 3.61^{\mathrm{a}}$ & $92.58 \pm 0.73^{\mathrm{c}, \mathrm{d}}$ \\
WPH_B2 & $99.50 \pm 1.04$ & $10.52 \pm 0.22^{\mathrm{b}}$ & $132.62 \pm 7.23^{\mathrm{a}}$ & $48.24 \pm 3.74^{\mathrm{a}}$ & $93.65 \pm 1.65^{\mathrm{b}, \mathrm{c}}$ \\
CONTROL & $97.55 \pm 2.10$ & $10.51 \pm 0.24^{\mathrm{b}}$ & $134.20 \pm 4.40^{\mathrm{a}}$ & $46.05 \pm 1.58^{\mathrm{a}}$ & $90.26 \pm 0.99^{\mathrm{d}}$ \\
\hline
\end{tabular}

${ }^{*}$ Means in the same column differ each other significantly $(P<0.05)$ 
(Table 2). The lactose content, of which $60-70 \%$ is not fermented ${ }^{15}$, did not differ among the yoghurt products and was at expected amounts. The mineral content was also affected by the ratio of addition and thus the WPC_A and MPM yoghurts contained the highest amounts of calcium and phosphorous (Table 3). Generally, the fortified yoghurts tended to contain more calcium and consequently to have higher nutritional value than control yoghurt.

Microbial counts in all produced yoghurts were at typical numbers (data not shown). Cells of St. thermophilus and L. bulgaricus in yoghurt type products should be alive and at numbers between $1 \times 10^{6}$ and $1 \times 10^{8} \mathrm{cfu} / \mathrm{g}^{15}$. Thermophilic lactococci counts in the produced yoghurts were $>1 \times 10^{7} \mathrm{cfu} / \mathrm{g}$ up to 21 days. In contrast, counts of $L$. bulgaricus decreased from $1 \times 10^{8}$ to $1 \times 10^{5} \mathrm{cfu} / \mathrm{g}$ at 21 days. This was attributed to the existed lactobacillus strain in the yoghurt culture used. It has been reported that the growth of yoghurt microorganisms in milk enriched with WPH depends on the microorganism strain ${ }^{16}$. No yeasts and moulds were detected in all yoghurts throughout storage.

$\mathrm{pH}$ of all yoghurts decreased dramatically from the $1^{\text {st }}$ to $14^{\text {th }}$ day of storage and remained almost constant up to the $21^{\text {st }}$ day (Fig. 1). MPM yoghurt presented the higher acidity throughout storage because of its higher protein content. The same yoghurt had also the highest $\mathrm{pH}$ value due to the buffering capacity of the kind of the added milk protein. Caseins contribute $36 \%$ to milk buffering capacity whereas whey proteins contribute only $5.4 \%$.

\section{Textural properties}

Water holding capacity (WHC) of yoghurts fortified with whey protein concentrates or with the blend of milk proteins was significantly $(P<0.05)$ higher than WHC of yoghurts fortified with whey protein hydrolysates or control yoghurt throughout storage (Fig. 2). Generally, as the protein content in the formulation increases a higher WHC is obtained ${ }^{4,5}$.

Hardness, a critical characteristic of set type yoghurt, increased in all yoghurts throughout storage (Fig. 3). As hardness is mainly influenced by the protein and total solids content ${ }^{3}$, MPM yoghurt enriched with the protein blend as well as the WPC_A and WPC_B yoghurts presented significantly $(P<0.05)$ higher hardness and adhesiveness than control or yoghurts fortified with WPH. The textural properties of yoghurts enriched with WPC depend mainly on the characteristics of the added powder ${ }^{3}$. In the case, however, of fortification with $\mathrm{WPH}$, the use of the experimentally made WPH of ovine/caprine origin resulted in the WPH_A yoghurt with significantly $(P<0.05)$ lower hardness and adhesiveness compared to control yoghurt. In general, yoghurt supplementation with either casein hydrolysates or whey protein hydrolysates at a ratio from 0.025 to $0.4 \%$ causes a more open and less

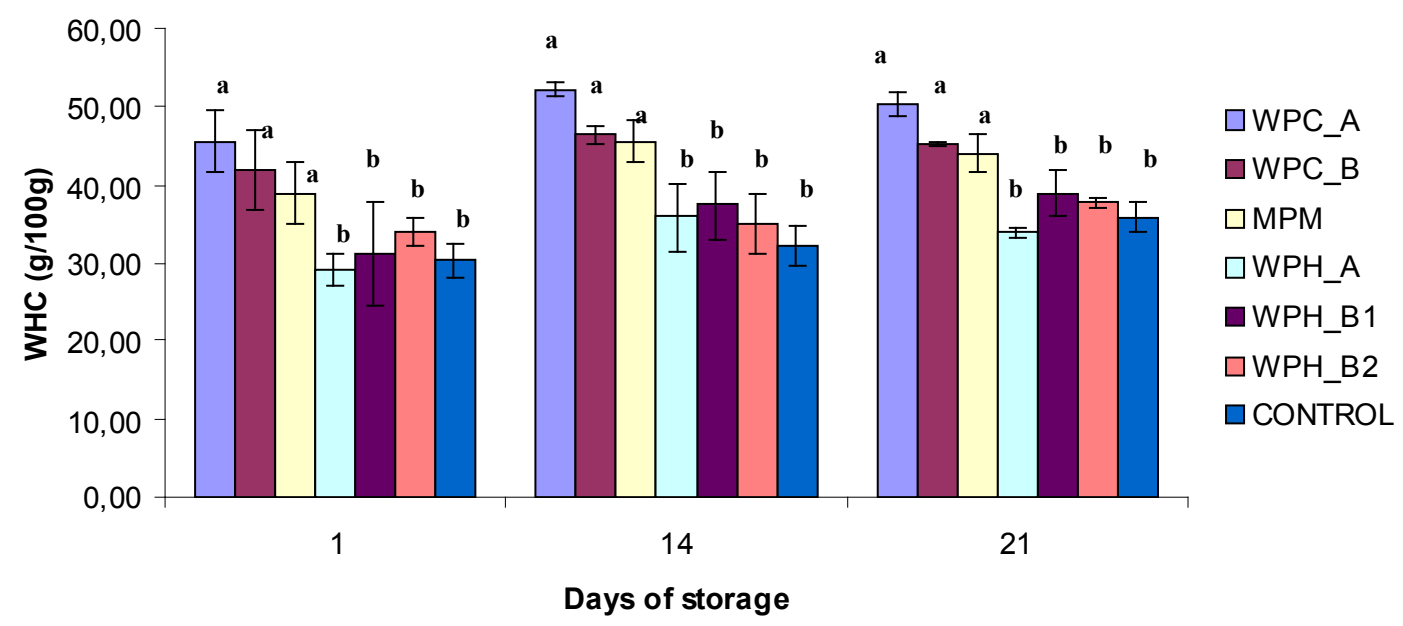

Fig.2: Water Holding Capacity (WHC) of low-fat bovine set-type yoghurts made with milk enriched with different whey protein powders 
branched structure ${ }^{17}$. Regarding cohesiveness, it did not differ among the different yoghurts (data not shown).

\section{Antioxidant properties}

The addition of whey protein did not increase the antioxidant activity of the produced yoghurts as far as the $\mathrm{DPPH}^{\cdot}$ radical scavenging activity concerns. The $\mathrm{DPPH}^{\circ}$ activity ranged from $44 \%$ to $57 \%$ at $1^{\text {st }}$ day and decreased to $36 \%-46 \%$ at 21 days of storage (Fig. 4). In contrast, the $\mathrm{Fe}^{2+}$ chelating activity of WPC_A yoghurt, MPM yoghurt and $\mathrm{WPH} \_\mathrm{A}$ yoghurt was $86 \%, 84 \%$ and $98 \%$ respectively at the $1^{\text {st }}$ day, decreasing slightly at the 21 days. Similar $\mathrm{Fe}^{+}$chelating activity values have been reported ${ }^{6}$ using higher ratio of added WPC. Yoghurt fortified with the experimental WPH of ovine/caprine origin presented significantly $(P<0.05)$ higher $\mathrm{Fe}^{+}$chelating activity throughout storage. It has been showed that the whey protein fractions derived from hydrolysis of whey with trypsin exhibit increased $\mathrm{Fe}^{+}$chelating activity ${ }^{18}$. Generally, the antioxidant potential of yoghurt is mainly due to the amino acids and small bioactive peptides, which are released during fermentation.

\section{ACE-inhibitory activity}

All yoghurts fortified with WPH exhibited higher ACE-inhibitory activity than the control yoghurt and all other enriched yoghurts (Fig.
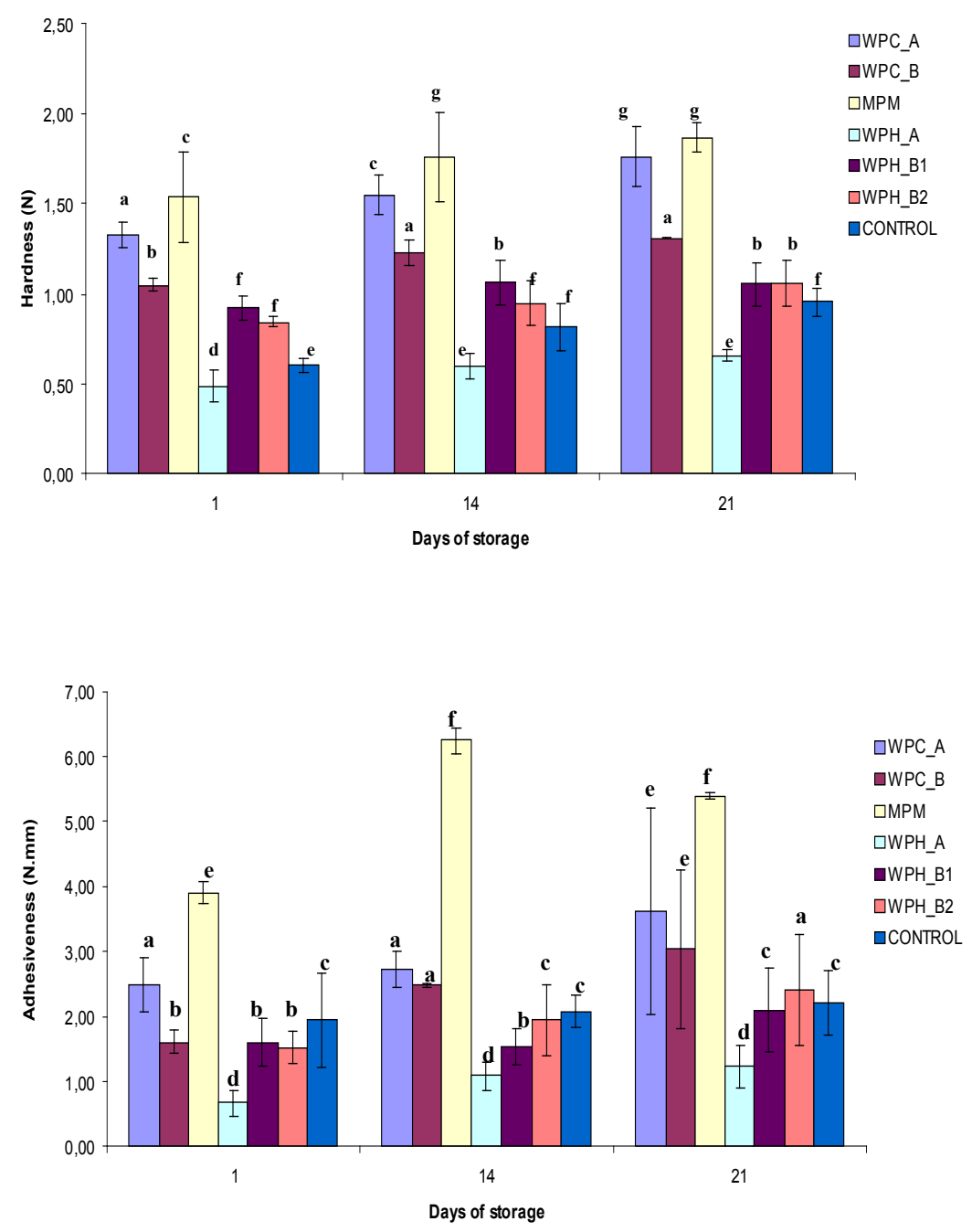

Fig.3: Textural properties of low-fat bovine set-type yoghurts made with milk enriched with different whey protein powders 

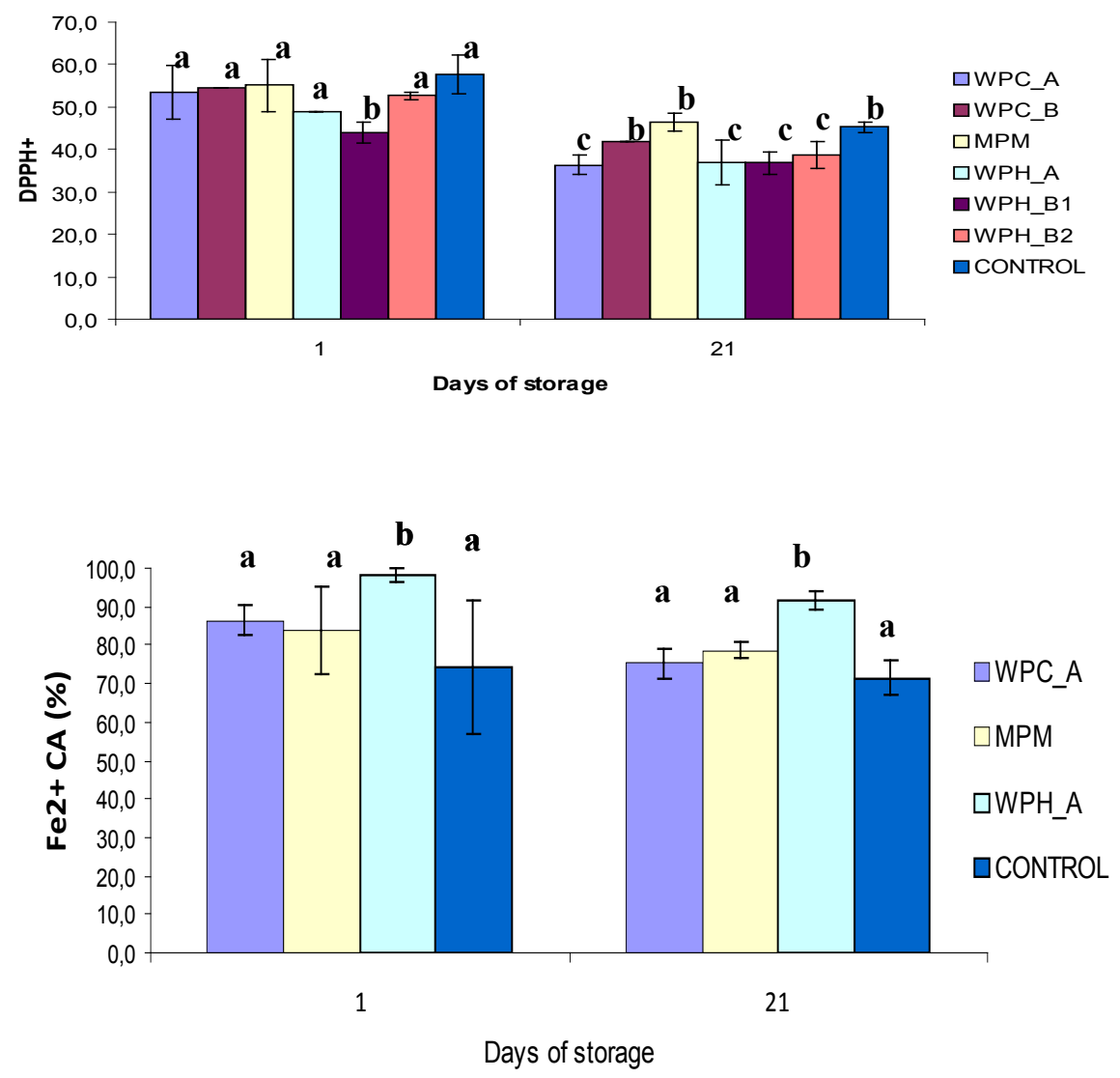

Fig.4: Antioxidant properties of low-fat bovine set-type yoghurts made with milk enriched with different whey protein powders

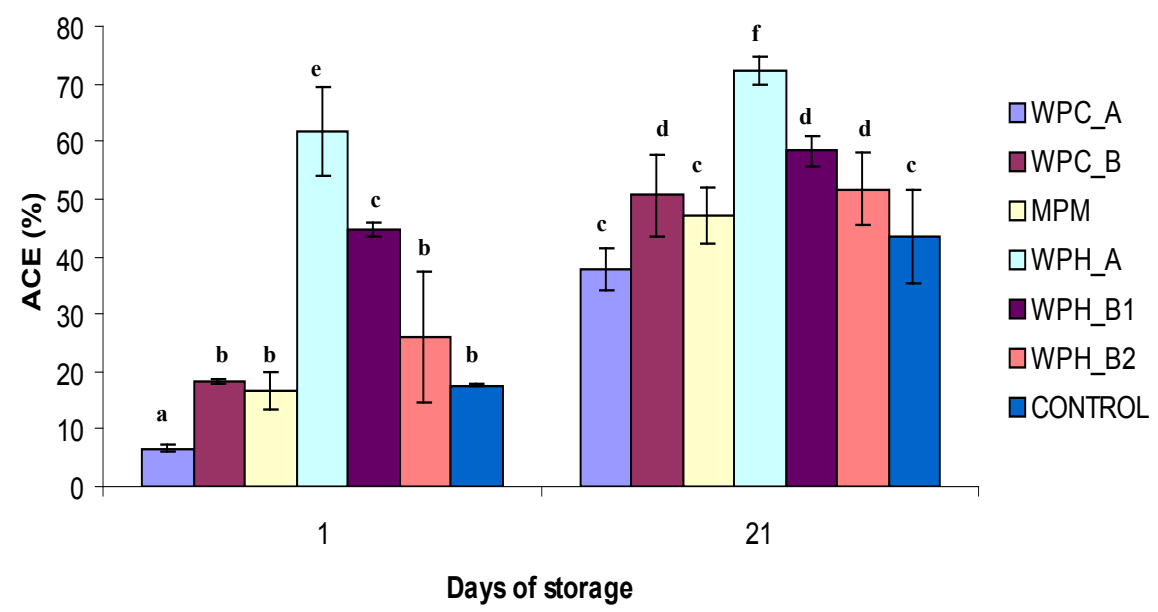

Fig.5: ACE-inhibitory activity of low-fat bovine set-type yoghurts made with milk enriched with different whey protein powders 
5). However, WPH_A yoghurt fortified with the experimental hydrolysate of ovine/caprine origin presented $>62 \%$ activity, which was significantly $(P<0.05)$ higher than the ACE-inhibitory activity of the other yoghurts up to 21 days. Bioactive peptides having ACE-inhibitory activity have been determined in experimental ovine yoghurts ${ }^{19,20}$, probiotic yoghurt 20,21, as well as in Greek commercial yoghurts ${ }^{22}$.

In conclusion, the fortification of low-fat bovine milk with WPC of different origin and at various ratios affected positively the textural properties of the produced set type yoghurts, whereas the fortification with WPH increased the biofunctional properties by the means of antioxidant and anti-hypertensive activity.

\section{ACKNOWLEDGEMENTS}

This research was supported by the Greek General Secretariat for Research \& Technology in the framework of the program SYNERGASIA II_2011.

\section{REFERENCES}

1. Shiby V.K, Mishra H.N. Fermented milks and milk products as Functional Foods-A review. Critical Reviews in Food Science and Nutrition; 53: 482-496: (2013).

2. Beltran - Barrientos L.M, Hernandez -Mendoza A, Torres-Llanez M.J, GonzalezCordova A. F, Vallejo-Cordoba B. Fermented milk as antihypertensive functional food. Journal of Diary Science; 99 (6): 4099-4110: (2016).

3. Karam M.C, Gaiani C, Hosri C, Burgain J, Scher J. Effect of dairy fortification on yogurt textural and sensorial properties: a review. Journal of Dairy Research; 80: 400-409: (2013).

4. Sodini I, Montella J, Tong P. Physical properties of yogurt fortified with various commercial whey protein concentrates. Journal of the Science of Food and Agriculture; 85: 853-859: (2005).

5. Unal G, Akalin A.S. Influence of fortification with sodium-calcium caseinate and whey protein concentrate on microbiological, textural and sensory properties of set-type yoghurt. International Journal of Dairy Technology; 66 (2): 264-272: (2013).

6. Unal G, Akalýn A. S. Antioxidant and angiotensin-converting enzyme inhibitory activity of yoghurt fortified with sodium calcium caseinate or whey protein concentrate. Dairy Science \& Technology; 92: 627-639: (2012).

7. Unal G, El S.N, Akalin A.S, Dinkci N. Antioxidant activity of probiotic yoghurt fortified with milk protein based ingredients. Italian Journal of Food Science; 25(1): 63-69: (2013).

8. Sakkas L, Lekaki E, Zoidou E, Moschopoulou E, Moatsou G. Development of Biofunctional Hydrolysates from Whey Protein Concentrates of ovine/caprine origin. Poster presentation In: Book of Abstracts of International Conference on Nutraceuticals and Functional Foods. 7-9 July, Kalamata, Greece; 116-117: (2016).

9. International Standard ISO 8070 / IDF 119 (2007). Milk and milk products Determination of calcium, sodium, potassium and magnesium content-Atomic absorption spectrometric method. Brussels: International Dairy Federation.

10. International Standard ISO 9847 / IDF 42 (2006). Milk - Determination of total phosphorous content - Method using molecular absorption spectrometry. Brussels: International Dairy Federation.

11. International Standard ISO 7889 / IDF 117 (2003). Yogurt - Enumeration of characteristic microorganisms - Colony-count technique at 37 degrees $C$. Brussels: International Dairy Federation.

12. International Standard ISO 6611 / IDF 94 (2004). Milk and milk products - Enumeration of colony-forming units of yeasts and/or moulds - Colony-count technique at 25 degrees $C$. Brussels: International Dairy Federation.

13. Kaminarides S, Anifantakis E. Characteristics of set type yoghurt made from caprine or ovine 
milk and mixtures of the two. International Journal of Food Science and Technology; 39: 319-324: (2004).

14. Jiang Z, Tian B, Brodkorb A, Huo G. Production, analysis and in vivo evaluation of novel angiotensin-I- converting enzyme inhibitory peptides from bovine casein. Food Chemistry; 123 (3): 779-786: (2010).

15. Robinson R.K, Itsaranuwat P. Properties of yoghurt and their appraisal. In Tamime A.Y. (Ed.) Fermented milks: 76-94: Blackwell Science, SDT, Oxford, UK. (2006).

16. McComas K.A, Gilliland S.E. Growth of probiotic and traditional yogurt cultures in milk supplemented with whey protein hydrolysate. Journal of Food Science; 68: 2090-2095: (2003).

17. Sodini I, Lucas A, Tissier J.P, Corrieu G. Physical properties and microstructure of yoghurts supplemented with milk protein hydrolysates International Dairy Journal; 15(1): 29-35: (2005).

18. Onay-Ucar E, Arda N, Pekmez M, Yilmaz A.M, Boke-Sarikahya N, Kirmizigul S. Yalcin A.S. Comparison of antioxidant capacity, protein profile and carbohydrate content of whey protein fractions. Food Chemistry; 150 (1): 34-40: (2014).

19. Chobert J.M, El-Zahar K, Sitohy M, Dalgalarrondo M, Choiset E, Haertle T. Angiotensin I-converting (ACE)-inhibitory activity of tryptic peptides of ovinelactoglobulin and of milk yoghurts obtained by using different starters. Lait; 85: 141-152: (2005).

20. Papadimitriou C.C, Vafopoulou-Mastrojiannaki A, Silva S.V, Gomes A.M, Malcata F.X, Alichanidis $E$. Identification of peptides in traditional and probiotic sheep milk yoghurt with angiotensin l-converting (ACE)-inhibitory activity. Food Chemistry; 105: 647-656: (2007).

21. Donkor O.N, Henriksson A, Singh T.K, Vasiljevic T, Shah N.P. ACE-inhibitory activity of probiotic yoghurt. International Dairy Journal; 17: 1321-1331: (2007).

22. Politis I, Theodorou G. Angiotensin I-converting (ACE)-inhibitory and anti-inflammatory properties of commercially available Greek yoghurt made from bovine or ovine milk: A comparative study. International Dairy Journal; 58: 46-49: (2016). 